\title{
Natural categories: Well defined or fuzzy sets?
}

\author{
MICHAEL E. McCLOSKEY and SAM GLUCKSBERG \\ Princeton University, Princeton, New Jersey 08540
}

\begin{abstract}
Thirty college students made category membership decisions for each of 540 candidate exemplar-category name pairs (e.g., apple-fruit) in each of two separate sessions. For highly typical category members (e.g., chair for the furniture category), and for items unrelated to a category (e.g., cucumber-furniture), subjects agreed with each other and were consistent in their decisions. However, for intermediate-typicality items (e.g., bookends-furniture), subjects disagreed with each other and were frequently inconsistent from one session to the next. These data suggest that natural categories are fuzzy sets, with no clear boundaries separating category members from nonmembers.
\end{abstract}

Recent research in semantic memory (cf. Smith, in press), as well as more traditional research in concept formation (cf. Bourne, Ekstrand, \& Dominowski, 1971) has generally assumed that natural categories are well defined sets of objects or events, with clear boundaries separating category members from nonmembers. For a well defined category, any given object or event may be unambiguously and nonarbitrarily classified as a member or nonmember of the category.

An alternative characterization of natural categories has been suggested by Wittgenstein (1953) and, more recently, by such psychologists as Hersch and Caramazza (1976), Kintsch (1974), Miller and Johnson-Laird (1976), and Rosch (1973; Rosch \& Mervis, 1975). These authors conceive of natural categories as vague or fuzzy sets (Zadeh, 1965) and argue that category membership is a matter of degree rather than all or none. Objects that are highly typical of a category (e.g., diamond for the category precious stone) are said to have a high degree of membership in the category. Less typical objects (e.g., zircon) have lower degrees of membership, while objects unrelated to the category (e.g., paper) have near-zero degrees of membership. An important implication of the fuzzy category notion is that no clear boundary exists between category members and nonmembers. Objects at the high and low extremes of the degree-of-membership continuum are clearly category members and nonmembers, respectively. Between these extremes, however, are items that cannot be clearly classified as either members or nonmembers of the category.

The possibility that categories are fuzzy rather than well defined has important implications for research and theory in concept formation and semantic memory.

This work was done while the first author held a National Science Foundation predoctoral fellowship. The research was supported by Public Health Service Research Grant MH 23401, S. Glucksberg, principal investigator. We thank Nancy McCloskey for her help in data analysis. Requests for reprints should be sent to Michael McCloskey, Psychology Department, Princeton University, Princeton, New Jersey 08540.
With few exceptions, laboratory concept-learning tasks have been designed to model well defined, specifiable categories. Similarly, recent models of semantic memory, whether they propose featural or propositional representations, assume that categories are well defined (e.g., Anderson \& Bower, 1973; Collins \& Quillian, 1969, 1970, 1972; Glass \& Holyoak, 1974/1975; Smith, Shoben, \& Rips, 1974). Unfortunately, the evidence bearing on this issue is inconclusive. Consider, for example, three recent findings. First, Rosch (1973) has shown that people can reliably rate the typicality of various members of a category. Furthermore, these ratings are correlated with performance in speeded verification tasks (e.g., Rips, Shoben, \& Smith, 1973; Rosch, 1973). Specifically, true category membership statements involving highly typical category examplars (e.g., A robin is a bird) are verified more quickly than statements involving less typical exemplars (e.g., A chicken is a bird). Finally, Oden (1977) has shown that people can reliably judge the relative truth value of category membership propositions. Oden's subjects, for example, judged the sentence "A robin is a bird" to be truer than the statement "A pelican is a bird." These findings clearly suggest that natural categories have an internal structure based on typicality or degree of membership of their exemplars, and thus support the fuzzy category hypothesis.

The typicality rating, verification latency, and truth judgment data do not, however, exclude the possibility that categories have clear boundaries. In fact, these results can easily be accommodated by semantic memory models that assume that categories are well defined. Propositional network models, for example, often assume that associative links between exemplar and category nodes vary in strength or ease of retrieval (Collins \& Quillian, 1972; Glass \& Holyoak, 1974/1975). These models can account for typicality ratings by assuming that exemplars rated as highly typical of a category are those with strong or easily retrieved links to the category node, while less typical exemplars are those with weaker links. Verification latencies and 
relative truth judgments could also be expected to covary with the strength of associative links between exemplar and category nodes.

In order to address the fuzzy vs. well defined category issue more directly, we adapted a procedure used by Hersch and Caramazza (1976). Subjects were presented with candidate-exemplar/category-name pairs (e.g., chair-furniture, pickle-vegetable) and were simply asked to decide whether or not the candidate exemplar was a member of the category. If categories are well defined, with clear boundaries, then any given candidate exemplar can be unambiguously and nonarbitrarily classified as a member or nonmember of a target category. Consequently, people should show substantial agreement with each other in their decisions about category membership. Furthermore, if we ask people to make category membership decisions for the same exemplar-category pairs on two separate occasions, each person should be consistent in his or her decisions (e.g., a candidate exemplar classified by a subject as a category member on one occasion should again be classified as a member on a subsequent occasion).

If, however, categories are fuzzy, high betweensubjects and within-subjects agreement should occur only for candidate exemplars with very high or very low degrees of membership in the category (i.e., those which are highly typical of the category or completely unrelated, respectively). Substantial disagreement among subjects should occur, however, for items with intermediate degrees of category membership (e.g. peanut for the vegetable category), because these items are neither clear category members, nor clear nonmembers. In addition, subjects should frequently be inconsistent in their decisions about intermediatemembership items. In other words, candidate exemplars classified by a subject as category members on one occasion should frequently be classified as nonmembers on a subsequent occasion, and vice versa.

\section{METHOD}

\section{Subjects}

Sixty-four men and women undergraduates at Princeton University served as paid volunteers. Thirty subjects served in the primary category membership decision group, 24 subjects provided typicality ratings for the stimulus pairs, and 10 subjects made exemplar-category partial overlap judgments.

\section{Materials}

Eighteen categories were selected from the Battig and Montague (1969) category norms. The following types of categories were excluded: (1) those with an insufficient number of familiar exemplars, such as "nonalcoholic beverages"; (2) those containing proper names, such as "a male's first name"; (3) those involving parts of a whole, such as "a part of the human body"; (4) those consisting of labels for people, such as "a military title" or "an occupation"; and (5) those defined by function, such as "a weapon."

For each of the 18 categories, we selected 30 candidate exemplars, ranging from highly typical category members (e.g., diamond for the category precious stone) through rather atypical items (e.g., onyx) to items completely unrelated to the category (e.g., paper). From these materials, 540 (30 for each of 18 categories) candidate-exemplar/category-name pairs (e.g., apple-fruit) were generated. The 540 pairs were typed, in one of two random orders (Orders $A$ and B), on 18 pages. The letters "Y," "N," and "U," which were used by subjects to indicate their responses, were typed to the right of each pair. Booklets for use in the primary category membership decision task were formed by randomly arranging the 18 pages. Thirty-five booklets were constructed from Randomization $\mathrm{A}$, and 35 from Randomization B.

Separate booklets of 18 pages, each containing a category name at the top and the 30 candidate exemplars listed below, were prepared for obtaining typicality ratings.

\section{Design and Procedure}

Thirty subjects completed the primary category membership decision task. Each subject participated in two sessions separated by approximately 1 month. In each of these two sessions, each subject made category membership decisions for all 540 candidate-exemplar/category-name pairs. Half of the subjects received Randomization A booklets in the first session and Randomization $B$ booklets in the second session, while the remaining half received B booklets in Session 1 and A booklets in Session 2.

Procedures in the two sessions were as identical as possible. Subjects were tested in groups of two to six people. Each subject was given a booklet, and the following instructions were read:

"If you will look on the front page of your booklet you'll see pairs of words. In each pair the second word is a category name-for example, 'furniture' or 'precious stone'-and the first word represents something which may or may not be a member of the category. Your task is to decide for each pair of words whether or not the first word represents a member of the category given by the second word. You should indicate your decision by circling one of the letters $\mathrm{Y}, \mathrm{N}$, or $\mathrm{U}$, which are listed beside each pair. If the word is a member of the category, you should circle $\mathrm{Y}$ for yes; if the word is not a member of the category, you should circle $\mathrm{N}$ for no. For example, you might see the pair 'dog-mammal.' Most people would agree that 'dog' is a member of the 'mammal' category, so for this pair you would probably circle $Y$.

"For all pairs you should simply give what seems to you to be the best answer. For some of the pairs this will be easy-it will be perfectly clear that the word is or is not a member of the category. For other pairs, however, the situation may not be so clear-cut, and it may be difficult to make a decision. Again, simply give what seems to you to be the best answer. I want to emphasize that you must make a yes-no decision for each pair, whether or not it seems clear-cut to you.

"There are two exceptions to this rule. First, if you do not know the meaning of one of the words in a pair, you should not make a yes-no decision for that pair. Instead, you should circle the $\mathrm{U}$ beside the pair, meaning that you are unfamiliar with the meaning of the word.

"Second, you should not make a yes-no decision if you feel that one of the words in a pair is ambiguous, and you can't tell which meaning is intended. For this type of pair, you should also circle $U$. This does not mean that you should circle $U$ whenever you come across a word which can have two meanings. In most cases the intended meaning will be clear from the context. If, for example, you saw the pair 'ring-jewelry' you would know that the ring you wear on your finger and not the ring of a telephone was being referred to. Again, you should only circle $\mathrm{U}$ when you cannot tell which meaning is intended.

"I want to emphasize that you should circle U only when you don't know the meaning of a word, or when a word is ambiguous. You should not use $\mathrm{U}$ simply to avoid making a decision when you feel that it is not clear-cut whether or not the word is a member of the category." 
Questions were then invited and were answered by paraphrasing from the printed instruction sheet. Subjects were then instructed to take enough time for each pair to make a decision, but not to linger over any individual item. In the second session, the subjects were told that some of the pairs they had judged in the first session might appear again. Most subjects completed the task within $50 \mathrm{~min}$.

An independent group of 24 subjects provided typicality ratings, which were used as a measure of the degree of membership of each candidate exemplar in its target category. The ratings employed a 10-point scale, with 10 meaning that the candidate exemplar was highly typical of the category, and 1 meaning that the exemplar was extremely atypical (i.e., unrelated). Subjects were instructed to apply the same standards of judgment to all 18 categories.

A third group of 10 subjects provided judgments of partial exemplar-category overlap. Between-subjects disagreement and within-subjects inconsistencies could occur with well defined categories if, for many of the candidate-exemplar/category-name pairs, some of the referents of the exemplar term were members of the category, and some were not. For a pair like "animal-pet," for example, inconsistencies and disagreements could occur if subjects sometimes decided that an animal was a pet because some animals are pets and sometimes said that an animal was not a pet because some animals are not pets. In order to identify and eliminate pairs of this type, in which the exemplar and category terms represent partially overlapping sets, the 10 subjects were asked to complete the membership task once. These subjects received the same instructions as did the primary subject group, but were also asked to indicate any pairs for which they felt that some of the referents of the exemplar term were members of the category, and some were not.

\section{RESULTS}

All candidate-exemplar/category-name pairs that were judged to represent partially overlapping sets by at least 1 subject in the 10-subject overlap judgment group were eliminated from the analysis of the data for the primary decision task. Forty-eight of the 540 pairs were so judged, and consequently the data reported below are for the remaining 492 items. In addition, pairs for which a subject circled " $U$ " in at least one session (less than $2 \%$ of the data) were eliminated from the analysis for that subject. The Appendix lists the 492 items and the data for each. Data for all dependent measures were compiled using both Session 1 and Session 2 category membership decisions made by the 30 subjects in the primary decision group.

The candidate-exemplar/category-name pairs were classified into nine typicality levels on the basis of the typicality ratings. Table 1 presents the number of exemplar-category pairs falling into each level. Level 1 represents extremely atypical items (i.e., those with ratings of 1.00-1.99), while Level 9 represents highly typical items (ratings of 9.00-10.00). As we had hoped, the stimulus items are distributed fairly evenly across typicality levels.

Figure 1 presents the mean proportion of "yes" responses (i.e., responses indicating that the candidate exemplar was a member of the category) as a function of typicality level. As expected, highly typical candidate
Table 1

Distribution of Candidate-Exemplar/Category-Name Pairs Across Typicality Levels

\begin{tabular}{lccc}
\hline \multirow{3}{*}{ High } & $\begin{array}{c}\text { Typicality } \\
\text { Level }\end{array}$ & $\begin{array}{c}\text { Corresponding } \\
\text { Typicality } \\
\text { Ratings }\end{array}$ & $\begin{array}{c}\text { Number } \\
\text { of Pairs }\end{array}$ \\
\hline \multirow{3}{*}{ Intermediate } & 9 & $9.00-10.00$ & 55 \\
& 8 & $8.00-8.99$ & 64 \\
& 7 & $7.00-7.99$ & 66 \\
Low & 6 & $6.00-6.99$ & 73 \\
& 5 & $5.00-5.99$ & 69 \\
& 4 & $4.00-4.99$ & 54 \\
& 3 & $3.00-3.99$ & 50 \\
& 2 & $2.00-2.99$ & 39 \\
& 1 & $1.00-1.99$ & 22 \\
\hline
\end{tabular}

exemplars were almost always classified as category members, while extremely atypical candidates were almost never so classified. These data indicate that subjects were in fact making category membership decisions for the pairs rather than, for example, responding randomly. The fact that the proportion of "yes" responses was between about .4 and .7 for intermediate-typicality items seems to suggest that subjects disagreed with each other in their decisions about these items. These proportions could also result, however, from the mixing of data from items for which all subjects said "yes" and items for which all said "no." Consequently, a different measure is needed to assess the extent of between-subjects disagreement.

We developed such a measure by calculating, for each item, the proportion of nonmodal, or minority, responses. Consider, for example, a pair for which $85 \%$ of the responses classified the candidate exemplar as a category member. For this item, the modal response is "yes" and the proportion of nonmodal responses is .15 , indicating that the minority opinion represented $15 \%$ of the responses. Complete agreement among subjects is represented by a .00 proportion of nonmodal responses, while maximal disagreement is represented by a proportion of .50 . This measure cannot spuriously indicate between-subjects disagreement by mixing data from pairs receiving primarily "yes" responses

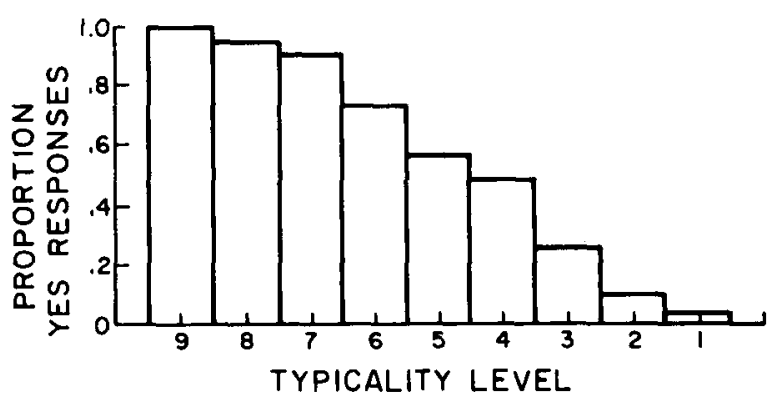

Figure 1. Mean proportion of "yes" responses as a function of typicality level. 


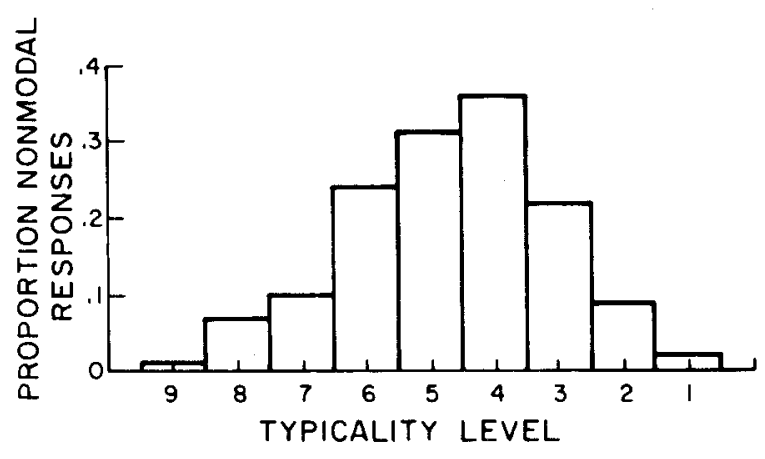

Figure 2. Mean proportion of nonmodal responses as a function of typicality level.

and pairs receiving primarily "no" responses. For example, the mean proportion of nonmodal responses calculated from a pair receiving $96 \%$ "yes" responses and a pair receiving 98\% "no" responses is .03 , indicating (correctly) high intersubject agreement for these two items.

Figure 2 presents the mean proportion of nonmodal responses as a function of typicality level. At very highand very low-typicality levels, between-subjects disagreement is very low. At intermediate-typicality levels, however, the data indicate substantial disagreement among subjects. The greatest disagreement occurred at typicality Level 4 , where the .36 proportion of nonmodal responses indicated that the majority opinion for a representative item at this typicality level comprised only $64 \%$ of the responses.

The conclusion that disagreement was higher at intermediate-typicality levels than at the extremes of the typicality range was confirmed by an analysis of variance. The analysis revealed that the proportion of nonmodal responses was not equivalent at high(Levels 7-9), intermediate- (Levels 4-6), and low(Levels 1-3) typicality levels $[F(2,34)=68.4, p<.01]$. Newman-Keuls tests indicated that the proportion of nonmodal responses was reliably greater for intermediate-typicality items than for either high-or low-typicality items ( $\mathrm{p}<.01$ for both comparisons). ${ }^{1}$

The high level of between-subjects disagreement for intermediate-typicality items is clearly consistent with the fuzzy category hypothesis. It is possible, however, that this disagreement represents variability among subjects in the placement of the boundaries of well defined categories. Thus, in order to distinguish between the fuzzy and well defined category positions, we must examine the extent of within-subjects inconsistency.

Thirty subjects made category membership decisions twice for 492 items, providing a total of 14,760 opportunities for within-subjects inconsistencies to occur. Figure 3 presents, for each typicality level, the proportion of opportunities for which inconsistencies did in fact occur. The proportion of .18 observed at Level 5, for example, indicates that within-subjects inconsistencies occurred for 362 of the 2,031 opportunities at that level.

As predicted by the fuzzy category hypothesis, within-subjects inconsistency was quite low at the extremes of the typicality range and quite high at intermediate-typicality levels. The greatest amount of inconsistency was obtained at typicality Level 4, where within-subjects inconsistencies occurred for fully $22 \%$ of the opportunities. This result may be described somewhat more concretely by saying that for a representative item at typicality Level 4 , about 7 of the 30 subjects made a different category membership decision in Session 2 than in Session 1.

The proportions of inconsistent responses at high(7-9), intermediate- (4-6), and low- (1-3) typicality levels were compared in analyses of variance using both categories and subjects as random factors, and a min $\mathrm{F}^{\prime}$ ratio was calculated (Clark, 1973). Within-subjects inconsistency was not equivalent in the three typicality regions $\left[\min F^{\prime}(2,62)=34.25, p<.01\right]$. Newman-Keuls tests using the error terms from both the subjects analysis and the categories analysis indicated that the proportion of within-subjects inconsistencies was reliably higher for intermediate-typicality items than for either high-or low-typicality items ( $p<.01$ for all comparisons).

The within-subjects inconsistency data clearly support the hypothesis that natural categories are fuzzy. However, one alternative explanation merits consideration. It might be argued that each category name used in the experiment represents two or more well defined categories in semantic memory. The category name "insect," for example, may represent a category in a zoological taxonomy and also a somewhat different category of common everyday usage. If this was the case, within-subjects inconsistencies for the insect category could have occurred when a subject based his decisions about insects on the zoological category in one session and the everyday category in the other session.

The notion of multiple functional categories per category name seems implausible for most of the categories we used, and in fact this notion is not supported by the data. Consider a situation in which

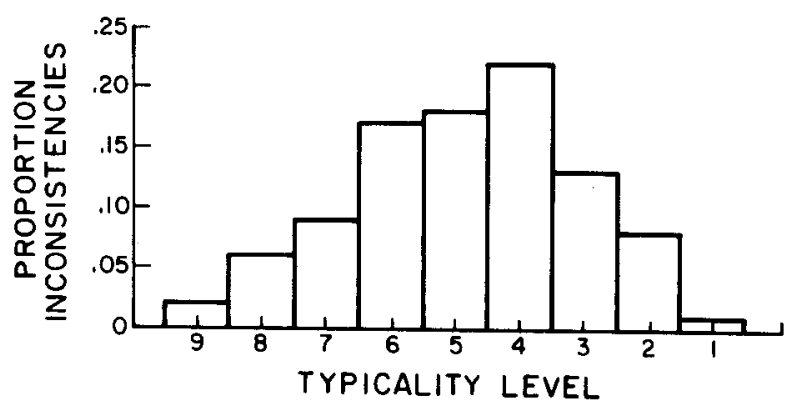

Figure 3. Mean proportion of within-subjects inconsistencies as a function of typicality level. 
a subject has two well defined functional insect categories. Assume that in each experimental session each of the two functional categories is equally likely to be chosen by the subject as the basis for decisions about insects. Under these conditions the probability that the same functional category will be used in both sessions is .5 , and the probability that different functional categories will be used is also .5. Equivalently, if 30 subjects make category membership decisions for a category in each of two sessions, 15 should use the same functional category in both sessions, and 15 should use different functional categories. Thus, if the only source of within-subjects inconsistencies is functional category switching, only half of the subjects should show within-subjects inconsistencies in their decisions about a given category. By the same logic, if a category name represents three functional categories, then only two-thirds (or 20 of the 30) subjects should show within-subjects inconsistencies for that category. ${ }^{2}$

Table 2 presents, for each of the 18 category names, the observed number of subjects showing one or more within-subjects inconsistencies for decisions about the category, together with the number predicted by the two- and three-categories-per-name hypotheses. Chisquare tests indicated that for 16 of the 18 categories, the observed number of subjects showing inconsistencies was reliably greater than the number predicted by the two-categories-per-name hypothesis. Furthermore, the observed number reliably exceeded that predicted by the three-categories-per-name hypothesis for 13 of the 18 categories. These results indicate that for most of the categories, the number of subjects showing inconsistencies was too great to be accounted for by

Table 2

Predicted (P) and Observed (O) Number of Subjects Showing Within-Subjects Inconsistencies

\begin{tabular}{|c|c|c|c|c|c|}
\hline \multirow[b]{3}{*}{ Category } & \multirow[b]{3}{*}{$\mathrm{O}$} & \multicolumn{4}{|c|}{ Categories Per Name } \\
\hline & & \multicolumn{2}{|r|}{ Two } & \multicolumn{2}{|c|}{ Three } \\
\hline & & $\mathrm{P}$ & $x^{2}$ & $\mathbf{P}$ & $x^{2}$ \\
\hline Animal & 28 & 15 & $20.83 *$ & 20 & $8.44^{*}$ \\
\hline Bird & 19 & 15 & 1.63 & 20 & .04 \\
\hline Carpenter's Tool & 24 & 15 & $9.63 *$ & 20 & 1.84 \\
\hline Clothing & 25 & 15 & $13.33^{*}$ & 20 & 3.03 \\
\hline Disease & 28 & 15 & $20.83^{*}$ & 20 & $8.44^{*}-1-x-1$ \\
\hline Fish & 29 & 15 & $24.30^{*}$ & 20 & $10.84^{*}$ \\
\hline Fruit & 26 & 15 & $14.70^{*}$ & 20 & $4.54^{*}$ \\
\hline Furniture & 30 & 15 & $28.03^{*}$ & 20 & $13.54^{*}$ \\
\hline Insect & 20 & 15 & 2.70 & 20 & 0.00 \\
\hline Kitchen Utensil & 30 & 15 & $28.03^{*}$ & 20 & $13.54^{*}$ \\
\hline Natural Earth Formation & 28 & 15 & $20.83^{*}$ & 20 & $8.44^{*}$ \\
\hline Precious Stone & 30 & 15 & $28.03 *$ & 20 & $13.54 *$ \\
\hline Science & 26 & 15 & $14.70^{*}$ & 20 & $4.54^{*}$ \\
\hline Ship & 26 & 15 & $14.70^{*}$ & 20 & $4.54 *$ \\
\hline Sport & 24 & 15 & $9.63^{*}$ & 20 & 1.84 \\
\hline Vegetable & 30 & 15 & $28.03^{*}$ & 20 & $13.54^{*}$ \\
\hline Vehicle & 27 & 15 & $17.63^{*}$ & 20 & $6.34 *$ \\
\hline Weather Phenomenon & 28 & 15 & $20.83^{*}$ & 20 & $8.44 *$ \\
\hline
\end{tabular}

assuming two or even three categories per category name. In fact, we would have to assume that, on average, each category name represented between eight and nine functional categories in order to account for the mean of 26.6 subjects per category who showed inconsistencies.

\section{DISCUSSION}

The substantial between-subjects disagreement and within-subjects inconsistency observed for membership decisions involving common natural categories strongly suggest that natural categories are fuzzy. These results are consistent with typicality rating (Rosch, 1973) and truth judgment (Oden, 1977) data in arguing that the potential exemplars of a category vary continuously in their degree of membership. Furthermore, our results suggest that no clear boundary separates category members from nonmembers.

While our data are consistent with this view, there are at least two other alternatives. One involves the possibility of well defined but multiple functional categories for each category name. We have already argued that the data are not consistent with functional category switching between sessions. Nevertheless, it is still possible that subjects switched functional categories from item to item within each session. Each category name appeared, on the average, once every 18 items. Within-sessions functional category switching could have occurred if subjects forgot the functional category they had last used during the intervals between appearances of the category names. This seems rather implausible, but the possibility cannot be excluded.

A second alternative is the "lack-of-knowledge" argument. One form of this argument is that many of the candidate exemplars are rather esoteric and unfamiliar to our subjects. Thus, even if they had well defined categories in semantic memory, their judgments would be inconsistent because they did not know enough about the unfamiliar exemplar items to decide about category memberships. This argument would be most convincing if between- and withinsubjects inconsistencies occurred primarily for relatively infrequent items like pterodactyl or euglena. However, quite common and familiar items like curtain, pillow, peanut, and button were classified inconsistently as often as the presumably less familiar items.

People may also have less than perfect knowledge of the category terms themselves. Therefore, while they may appear to have vague and fuzzy notions about the criteria for category memberships, they could in principle learn more about such categories and then be perfectly consistent in their judgments. This argument would be appropriate if our aim were to characterize idealized categories independently of people's ordinary conceptual knowledge. A technical taxonomy would be an example of such an idealized category system. But such systems, while useful and 
interesting in themselves, are not our concern here. Instead, our aim is to determine whether people's representations of ordinary categories are well defined or not. Our data seem to indicate that they are not. The possibility that people may be able to learn well defined if arbitrary category membership criteria is irrelevant to our present purpose. Both lack-ofknowledge arguments, then, seem unpersuasive, even though they cannot be unequivocally rejected.

If natural categories are indeed fuzzy, as our data strongly suggest, then how might they be represented in semantic memory? To the extent that the representations proposed by the two major classes of semantic memory models include defining or criterial properties of natural categories, to that extent might they be inadequate. One such class of models (e.g., Meyer, 1970; Smith et al., 1974) assumes that categories are represented as sets of defining or criterial features that specify necessary and sufficient conditions for category membership. This type of representation would be inappropriate, because fuzzy categories by definition lack necessary conditions for membership.

A second class of models (e.g., Anderson \& Bower, 1973; Collins \& Quillian, 1972; Glass \& Holyoak, 1974/1975) represents categories and their exemplars as nodes in a propositional network, with each exemplar node connected to the category node by a link specifying the category membership relation. This type of network can represent the fact that an item is a member or a nonmember of a category by the presence or absence of a category membership link between the item and the category. However, this representation cannot easily express the continuous variation in degree of membership evidenced by the exemplars of a fuzzy category. In particular, the use of category membership links does not suffice to represent items with intermediate degrees of membership, since these are neither clear category members nor clear nonmembers.

One might assume multiple types of representations for information, such that category membership links are used for exemplars with high degrees of membership and other forms of representation are employed for intermediate-membership items. Parsimony, however, argues against multiple representational types.

Alternatively, one might represent category membership information in terms of propositions that explicitly specify a potential exemplar's degree of membership in a category. Propositions of this type might, for example, assert that "canary" has a high degree of membership in the category "bird," and that "ostrich" has a low degree of membership. While this type of representation allows for continuous variation in degree of membership, it says nothing about why some potential exemplars of a category have a higher degree of membership than others.

A third possibility is that categories are represented as sets of properties or attributes that are characteristic and not defining (McCloskey \& Glucksberg, Note 1). A characteristic property is one which is possessed by many of the category's exemplars but which does not represent a necessary condition for category membership (cf. Smith et al., 1974). Because all properties are assumed to be characteristic rather than defining, necessary conditions for membership in a category do not exist.

For a category conceived of in this way, a potential exemplar's degree of membership is determined by the proportion of the category's properties that it shares. Items sharing a large proportion of the category's properties have a high degree of membership in the category, while items sharing few of these properties have a low degree of membership. Degree of membership thus varies continuously, and no sharp boundary separates category members from nonmembers. A similar and somewhat more detailed proposal has already been made by Rosch and Mervis (1975), who argue that a potential exemplar's degree of membership in a category is directly proportional to the number of attributes it shares with other members of the category, and inversely proportional to the number of attributes it shares with members of other categories.

Although many other types of representation for fuzzy categories can certainly be formulated, characteristic property representations have the advantage of offering a plausible basis for variation among category exemplars in degree of membership (i.e., degree of membership is defined in terms of properties shared by exemplar and category). In addition, this representation is consistent with the results of a large body of research in semantic memory (cf. McCloskey \& Glucksberg, Note 1).

While the present experiment does not argue strongly for one particular type of representation for natural categories, the data do argue against the notion of well defined categories with specifiable conditions for membership. Consequently, it seems that conceptformation and concept-identification paradigms, which model well defined categories, may not be well suited for studying the categorization processes employed by people in everyday life. Finally, our results indicate that theories of semantic memory that assume well defined categories may not accurately reflect how category information is represented in memory.

Appendix

Data for Individual Stimuli

\begin{tabular}{|c|c|c|c|c|}
\hline $\begin{array}{l}\text { Candidate } \\
\text { Exemplar }\end{array}$ & $\begin{array}{l}\text { Typi- } \\
\text { cality }\end{array}$ & $\mathrm{MR}^{*}$ & $\mathrm{NR}^{*}$ & WI* \\
\hline & \multicolumn{4}{|c|}{ Animal Category } \\
\hline Dog & 10.00 & Y & .02 & .03 \\
\hline Horse & 9.83 & $\mathrm{Y}$ & .00 & .00 \\
\hline Cow & 9.75 & $\mathrm{Y}$ & .00 & .00 \\
\hline Sparrow & 7.50 & Y & .13 & .13 \\
\hline Cobra & 6.75 & $\mathrm{Y}$ & .07 & .10 \\
\hline Trout & 6.66 & $\mathrm{Y}$ & .20 & .07 \\
\hline
\end{tabular}




\begin{tabular}{|c|c|c|c|c|c|c|c|c|c|}
\hline $\begin{array}{r}\text { Candidate } \\
\text { Exemplar }\end{array}$ & $\begin{array}{l}\text { Typi- } \\
\text { cality }\end{array}$ & $\mathrm{MR}^{*}$ & $\mathrm{NR}^{*}$ & $\mathrm{WI}^{*}$ & $\begin{array}{l}\text { Candidate } \\
\text { Exemplar }\end{array}$ & $\begin{array}{l}\text { Typi- } \\
\text { cality }\end{array}$ & $\mathrm{MR}^{*}$ & NR* & WI* \\
\hline Lizard & 6.50 & $\mathrm{Y}$ & .07 & .07 & & \multicolumn{4}{|c|}{ Clothing Category } \\
\hline Unicorn & 6.14 & $\mathrm{Y}$ & .17 & .07 & Dress & 9.92 & $\mathrm{Y}$ & .00 & .00 \\
\hline Lobster & 6.13 & $\mathrm{Y}$ & .17 & .13 & Shirt & 9.92 & $\mathrm{Y}$ & .00 & .00 \\
\hline Jelly fish & 5.92 & $\mathbf{Y}$ & .12 & .17 & Necktie & 9.04 & $\mathrm{Y}$ & .03 & .07 \\
\hline Woman & 5.54 & $\mathrm{Y}$ & .03 & .07 & Socks & 8.92 & $\mathrm{Y}$ & .03 & .07 \\
\hline Worm & 5.30 & $\mathrm{Y}$ & .10 & .07 & Shoes & 8.79 & $\mathrm{Y}$ & .08 & .10 \\
\hline Tadpole & 5.21 & $\mathrm{Y}$ & .13 & .13 & Cuff Links & 6.79 & $\mathrm{~N}$ & .32 & .23 \\
\hline Spider & 5.16 & $\mathrm{Y}$ & .22 & .10 & Buttons & 6.17 & $\mathrm{~N}$ & .32 & .30 \\
\hline Mosquito & 4.92 & $\mathrm{Y}$ & .20 & .13 & Bracelet & 5.83 & $\mathrm{~N}$ & .18 & .17 \\
\hline Amoeba & 4.21 & $\mathrm{Y}$ & .17 & .21 & Necklace & 5.79 & $\mathbf{N}$ & .26 & .07 \\
\hline Poet & 4.04 & $\mathrm{Y}$ & .35 & .23 & Handkerchief & 5.71 & $\mathrm{~N}$ & .45 & .10 \\
\hline Sea Anemone & 3.92 & $\mathrm{Y}$ & .12 & .11 & Wig & 5.33 & $\mathrm{~N}$ & .37 & .13 \\
\hline Hydra & 3.77 & $\mathrm{Y}$ & .12 & .11 & Watch & 5.25 & $\mathrm{~N}$ & .17 & .13 \\
\hline Euglena & 3.60 & $\mathrm{Y}$ & .15 & .20 & Handbag & 4.96 & $\mathrm{~N}$ & .32 & .17 \\
\hline Sponge & 3.58 & $\mathrm{Y}$ & .16 & .10 & Eyeglasses & 4.83 & $\mathbf{N}$ & .15 & .17 \\
\hline Cocoon & 3.46 & $\mathrm{~N}$ & .22 & .24 & Cane & 4.67 & $\mathrm{~N}$ & .03 & .07 \\
\hline E.gg & 3.38 & $\mathrm{~N}$ & .24 & .14 & Corsage & 4.29 & $\mathrm{~N}$ & .22 & .10 \\
\hline Bacterium & 3.29 & $\mathrm{Y}$ & .33 & .17 & Wallet & 4.08 & $\mathrm{~N}$ & .17 & .10 \\
\hline Yeast & 2.50 & $\mathrm{Y}$ & .47 & .33 & Makeup & 3.96 & $\mathrm{~N}$ & .10 & .13 \\
\hline Fungus & 2.30 & $\mathbf{N}$ & .38 & .21 & Medal & 3.96 & $\mathrm{~N}$ & .05 & .03 \\
\hline Virus & 2.30 & $\mathrm{~N}$ & .33 & .17 & Umbrella & 3.83 & $\mathrm{~N}$ & .10 & .13 \\
\hline Tree & 1.33 & $\mathrm{~N}$ & .00 & .00 & Fingernail Polish & 3.67 & $\mathrm{~N}$ & .05 & .03 \\
\hline Tulip & 1.33 & $\mathrm{~N}$ & .00 & .00 & Contact Lens & 3.58 & $\mathrm{~N}$ & .07 & .00 \\
\hline \multirow[t]{2}{*}{ Car } & 1.00 & $\mathrm{~N}$ & .00 & .00 & Briefcase & 3.21 & $\mathrm{~N}$ & .00 & .00 \\
\hline & \multicolumn{4}{|c|}{ Bird Category } & Dentures & 3.08 & $\mathrm{~N}$ & .03 & .00 \\
\hline Robin & 10.00 & $\mathrm{Y}$ & .00 & 00 & Suitcase & 2.92 & $\mathrm{~N}$ & .02 & .03 \\
\hline $\begin{array}{l}\text { Kobin } \\
\text { Snarrow }\end{array}$ & $\begin{array}{r}10.00 \\
9.96\end{array}$ & $\begin{array}{l}Y \\
Y\end{array}$ & $\begin{array}{r}.00 \\
00\end{array}$ & .00 & Beard & 2.71 & $\mathrm{~N}$ & .00 & .00 \\
\hline $\begin{array}{l}\text { Sparrow } \\
\text { Eagle }\end{array}$ & $\begin{array}{l}9.96 \\
9.58\end{array}$ & $\begin{array}{l}Y \\
Y\end{array}$ & $\begin{array}{l}.00 \\
.00\end{array}$ & $\begin{array}{l}.00 \\
00\end{array}$ & Hearing Aid & 2.67 & $\mathrm{~N}$ & .05 & .03 \\
\hline $\begin{array}{l}\text { Eagle } \\
\text { Owl }\end{array}$ & $\begin{array}{l}9.58 \\
8.71\end{array}$ & $\begin{array}{l}Y \\
Y\end{array}$ & $\begin{array}{l}.00 \\
.00\end{array}$ & $\begin{array}{l}.00 \\
.00\end{array}$ & Hairbrush & 2.17 & $\mathrm{~N}$ & .02 & .03 \\
\hline $\begin{array}{l}\text { Partridge } \\
\text { Par }\end{array}$ & $\begin{array}{l}8.71 \\
8.42\end{array}$ & $\mathbf{Y}$ & $\begin{array}{l}.00 \\
.00\end{array}$ & $\begin{array}{l}.00 \\
.00\end{array}$ & Bandaid & 1.79 & $\mathrm{~N}$ & .03 & .00 \\
\hline Vulture & 8.38 & $\mathrm{Y}$ & .00 & .00 & & \multicolumn{4}{|c|}{ Disease Category } \\
\hline Goose & 8.29 & $\mathrm{Y}$ & .03 & .07 & Cancer & 9.75 & $\mathrm{Y}$ & .00 & .00 \\
\hline Duck & 8.25 & $\mathrm{Y}$ & .03 & .07 & Tuberculosis & 9.67 & $\mathrm{Y}$ & .00 & .00 \\
\hline Condor & 8.23 & $\mathrm{Y}$ & .00 & .00 & Measles & 9.25 & $\mathrm{Y}$ & .05 & .10 \\
\hline Pheasant & 8.17 & $\mathrm{Y}$ & .00 & .00 & Leprosy & 8.42 & $\mathrm{Y}$ & .00 & .00 \\
\hline Buzzard & 8.08 & $\mathrm{Y}$ & .02 & .03 & Epilepsy & 8.13 & $\mathrm{Y}$ & .02 & .03 \\
\hline Rooster & 7.96 & $\mathrm{Y}$ & .03 & .07 & Asthma & 8.04 & $\mathrm{Y}$ & .07 & .07 \\
\hline Turkey & 7.92 & $\mathrm{Y}$ & .00 & .00 & Gangrene & 7.75 & $\mathrm{Y}$ & .12 & .17 \\
\hline Quail & 7.88 & $\mathrm{Y}$ & .00 & .00 & Arthritis & 7.67 & $\mathrm{Y}$ & .07 & .13 \\
\hline Chicken & 7.75 & $\mathrm{Y}$ & .05 & .03 & Heart Attack & 7.08 & $\mathrm{~N}$ & .48 & .23 \\
\hline Albatross & 7.52 & $\mathrm{Y}$ & .05 & .10 & High Blood Pressure & 6.88 & $\mathbf{Y}$ & .27 & .20 \\
\hline Loon & 7.43 & $\mathrm{Y}$ & .00 & .00 & Alcoholism & 6.71 & $\mathrm{Y}$ & .08 & .10 \\
\hline Pelican & 7.29 & $\mathrm{Y}$ & .03 & .00 & Paralysis & 6.58 & $\mathrm{Y}$ & .45 & .30 \\
\hline Ostrich & 7.25 & $\mathrm{Y}$ & .03 & .07 & Drug Addiction & 6.50 & $\mathrm{Y}$ & .22 & .17 \\
\hline Dodo & 7.13 & $\mathrm{Y}$ & .02 & .03 & Allergy & 6.29 & $\mathrm{Y}$ & .42 & .23 \\
\hline Penguin & 6.96 & $\mathrm{Y}$ & .08 & .13 & Stroke & 6.29 & $\mathrm{Y}$ & .48 & .37 \\
\hline Pterodactyl & 4.96 & $\mathrm{Y}$ & .44 & .13 & Fever & 6.25 & $\mathrm{~N}$ & .35 & .23 \\
\hline Bat & 3.63 & $\mathbf{N}$ & .17 & .13 & Schizophrenia & 6.04 & $\mathrm{Y}$ & .05 & .03 \\
\hline Chicken Egg & 2.96 & $\mathrm{~N}$ & .27 & .27 & Ulcer & 5.88 & $\mathrm{Y}$ & .33 & .20 \\
\hline Flying Squirrel & 2.63 & $\mathrm{~N}$ & .05 & .03 & Neurosis & 5.75 & $\mathrm{Y}$ & .22 & .17 \\
\hline Butterfly & 2.38 & $\mathrm{~N}$ & .05 & .03 & Tooth Decay & 5.50 & $\mathrm{Y}$ & .30 & .13 \\
\hline Vampire & 2.29 & $\mathrm{~N}$ & .13 & .13 & Food Poisoning & 5.46 & $\mathrm{Y}$ & .47 & .27 \\
\hline Bee & 2.04 & $\mathrm{~N}$ & .03 & .00 & Blindness & 4.71 & $\mathrm{~N}$ & .43 & .40 \\
\hline \multirow[t]{3}{*}{ Locust } & 1.83 & $\mathrm{~N}$ & .09 & .10 & Dandruff & 4.71 & $\mathrm{~N}$ & .32 & .30 \\
\hline & \multirow{2}{*}{\multicolumn{4}{|c|}{ Carpenter's Tool Category }} & Deafness & 4.71 & $N$ & .45 & .34 \\
\hline & & & & & Depression & 4.04 & $\mathrm{~N}$ & .45 & .34 \\
\hline Saw & 9.83 & $Y$ & .00 & .00 & Nearsightedness & 4.04 & $\mathrm{~N}$ & .27 & .20 \\
\hline Sandpaper & 8.54 & $\hat{\mathrm{Y}}$ & .03 & .07 & Friendliness & 1.17 & $\mathrm{~N}$ & .00 & .00 \\
\hline Nails & 8.46 & $\mathrm{Y}$ & .20 & .27 & Happiness & 1.17 & $\mathrm{~N}$ & .00 & .00 \\
\hline Workbench & 8.13 & $\mathrm{Y}$ & .32 & .23 & & \multirow{2}{*}{\multicolumn{4}{|c|}{ Fish Category }} \\
\hline Vise & 7.88 & $\mathrm{Y}$ & .00 & .00 & & & & & \\
\hline Varnish & 5.71 & $\mathrm{~N}$ & .45 & .30 & Trout & 9.91 & $\mathrm{Y}$ & .00 & .00 \\
\hline Soldering Iron & 5.50 & $\mathrm{Y}$ & .42 & .10 & Salmon & 9.75 & $\mathrm{Y}$ & .02 & .03 \\
\hline Crowbar & 5.08 & $\mathrm{Y}$ & .08 & .17 & Cod & 9.63 & $\mathrm{Y}$ & .00 & .00 \\
\hline Sledge Hammer & 4.74 & $\mathrm{Y}$ & .37 & .27 & Flounder & 9.58 & $\mathrm{Y}$ & .00 & .00 \\
\hline Calculator & 3.29 & $\mathbf{N}$ & .28 & .23 & Tuna & 9.50 & $\mathrm{Y}$ & .02 & .03 \\
\hline
\end{tabular}




\begin{tabular}{|c|c|c|c|c|c|c|c|c|c|}
\hline $\begin{array}{l}\text { Candidate } \\
\text { Exemplar }\end{array}$ & $\begin{array}{l}\text { Typi- } \\
\text { cality }\end{array}$ & $\mathrm{MR}^{*}$ & $\mathrm{NR}^{*}$ & $\mathrm{WI}^{*}$ & $\begin{array}{l}\text { Candidate } \\
\text { Exemplar }\end{array}$ & $\begin{array}{l}\text { Typi- } \\
\text { cality }\end{array}$ & $\mathrm{MR}^{*}$ & $\mathrm{NR}^{*}$ & WI* \\
\hline Shark & 8.25 & $\mathrm{Y}$ & .20 & .13 & Refrigerator & 5.07 & $\mathrm{~N}$ & .18 & .23 \\
\hline Eel & 6.83 & $\mathrm{Y}$ & .18 & .23 & Curtains & 4.78 & $\mathrm{~N}$ & .30 & .33 \\
\hline Squid & 6.30 & $\mathrm{Y}$ & .40 & .27 & Waste Basket & 4.70 & $\mathrm{~N}$ & .31 & .30 \\
\hline Shrimp & 6.17 & $Y$ & .38 & .30 & Bookends & 4.53 & $\mathrm{~N}$ & .43 & .20 \\
\hline Stingray & 6.09 & $Y$ & .13 & .13 & Ironing Board & 4.32 & $\mathbf{N}$ & .16 & .13 \\
\hline Jelly fish & 5.75 & $\mathrm{Y}$ & .40 & .20 & Candlestick & 4.20 & $N$ & .28 & .30 \\
\hline Lobster & 5.71 & $\mathrm{~N}$ & .47 & .27 & Pillow & 4.12 & $N$ & .31 & .30 \\
\hline Whale & 5.71 & $N$ & .17 & .07 & Potted Plant & 3.91 & $\mathrm{~N}$ & .10 & .06 \\
\hline Octopus & 5.66 & $\mathrm{~N}$ & .45 & .17 & Electric Fan & 3.78 & $\mathbf{N}$ & .13 & .06 \\
\hline Porpoise & 5.63 & $\mathrm{~N}$ & .33 & .27 & Telephone & 3.62 & $\mathrm{~N}$ & .08 & .10 \\
\hline Starfish & 5.58 & $\mathrm{Y}$ & .43 & .20 & Ashtray & 3.45 & $\mathrm{~N}$ & .21 & .10 \\
\hline Seal & 5.48 & $\mathrm{~N}$ & .13 & .14 & Blackboard & 3.25 & $\mathrm{~N}$ & .15 & .16 \\
\hline Lamprey & 5.47 & $\mathrm{Y}$ & .20 & .22 & Door & 2.87 & $\mathbf{N}$ & .10 & .13 \\
\hline Clam & 5.25 & $N$ & .45 & .10 & Window & 2.53 & $\mathrm{~N}$ & .00 & .00 \\
\hline Sea Horse & 5.09 & $\mathrm{Y}$ & .38 & .23 & Ceiling & 2.03 & $\mathrm{~N}$ & .00 & .00 \\
\hline Crab & 4.95 & $\mathrm{~N}$ & .42 & .30 & Fence & 1.87 & $\mathrm{~N}$ & .00 & .00 \\
\hline Tadpole & 4.87 & $\mathrm{~N}$ & .23 & .20 & & \multirow{2}{*}{\multicolumn{4}{|c|}{ Insect Category }} \\
\hline Oyster & 4.83 & $\mathbf{N}$ & .45 & .23 & & & Y & .00 & .00 \\
\hline Sea Cow & 4.57 & $\mathrm{~N}$ & .28 & .05 & Fly & 9.79 & $\begin{array}{l}\mathbf{Y} \\
\mathrm{Y}\end{array}$ & 00 & \\
\hline Salamander & 4.13 & $\mathrm{~N}$ & .23 & .07 & Mosquito & 9.79 & $\begin{array}{l}\mathrm{Y} \\
\mathrm{Y}\end{array}$ & 00 & .00 \\
\hline Sea Anemone & 3.96 & $\mathrm{~N}$ & .45 & .07 & Ant & 9.42 & & & .00 \\
\hline Sponge & 3.45 & $\mathbf{N}$ & .38 & .32 & Wasp & 9.21 & $\mathrm{Y}$ & .00 & .00 \\
\hline Plankton & 3.12 & $\mathrm{~N}$ & .32 & .21 & Beetle & 8.96 & $\mathrm{Y}$ & .00 & .00 \\
\hline Alligator & 2.71 & $\mathrm{~N}$ & .10 & .20 & Bee & 8.88 & $\mathrm{Y}$ & .03 & .07 \\
\hline \multirow[t]{3}{*}{ Otter } & 2.70 & $\mathrm{~N}$ & .13 & .07 & Flea & 8.83 & $\mathrm{Y}$ & .02 & .03 \\
\hline & \multirow{2}{*}{\multicolumn{4}{|c|}{ Fruit Category }} & Moth & 8.71 & $\mathrm{Y}$ & .02 & .03 \\
\hline & & & & & Locust & 8.63 & $\mathrm{Y}$ & .02 & .03 \\
\hline Apple & 9.92 & $\mathrm{Y}$ & .00 & .00 & Firefly & 8.58 & $Y$ & .00 & .00 \\
\hline Banana & 9.58 & $Y$ & .07 & .07 & Grasshopper & 8.50 & $\mathrm{Y}$ & .00 & .00 \\
\hline Pineapple & 9.00 & $Y$ & .02 & .03 & Termite & 8.38 & $Y$ & .00 & .00 \\
\hline Strawberry & 8.96 & $\mathrm{Y}$ & .00 & .00 & Butterfly & 8.13 & $\mathrm{Y}$ & .00 & .00 \\
\hline Canteloupe & 8.25 & $Y$ & .03 & .07 & Caterpillar & 7.63 & $\mathrm{Y}$ & .05 & .10 \\
\hline Mango & 8.13 & $Y$ & .00 & .00 & Centipede & 7.63 & $\mathrm{Y}$ & .20 & .07 \\
\hline Watermelon & 7.88 & $\mathrm{Y}$ & .02 & .03 & Millipede & 7.50 & $\mathrm{Y}$ & .22 & .10 \\
\hline Papaya & 7.64 & $\mathrm{Y}$ & .00 & .00 & Spider & 7.21 & $\mathrm{Y}$ & .25 & .10 \\
\hline Fig & 7.42 & $\mathrm{Y}$ & .02 & .03 & Louse & 6.30 & $\mathrm{Y}$ & .05 & .03 \\
\hline Cranberry & 7.38 & $\mathrm{Y}$ & .03 & .07 & Tarantula & 6.26 & $\mathrm{Y}$ & .27 & .11 \\
\hline Raisin & 7.25 & $Y$ & .05 & .03 & Silkworm & 6.21 & $\mathrm{Y}$ & .08 & .10 \\
\hline Pomegranate & 7.05 & $Y$ & .00 & .00 & Scorpion & 5.33 & $Y$ & .22 & .10 \\
\hline Coconut & 6.83 & $Y$ & .15 & .17 & Leech & 4.92 & $\mathrm{Y}$ & .42 & .10 \\
\hline Avocado & 5.58 & $\mathrm{Y}$ & .28 & .17 & Worm & 4.79 & $\mathbf{N}$ & .47 & .27 \\
\hline Orange Juice & 5.58 & $\mathrm{~N}$ & .25 & .17 & Bacterium & 2.88 & $\mathrm{~N}$ & .00 & .00 \\
\hline Pumpkin & 5.42 & Y & .47 & .27 & Amoeba & 2.46 & $\mathrm{~N}$ & .00 & .00 \\
\hline Tomato & 5.17 & $\mathrm{Y}$ & .20 & .20 & Salamander & 2.33 & $\mathrm{~N}$ & .03 & .10 \\
\hline Olive & 4.04 & $\mathrm{Y}$ & .40 & .33 & Sea Horse & 2.25 & $\mathrm{~N}$ & .07 & .07 \\
\hline Acorn & 3.79 & $\mathrm{~N}$ & .40 & .27 & Bat & 2.04 & $\mathrm{~N}$ & .07 & .07 \\
\hline Cucumber & 3.42 & $N$ & .28 & .23 & Mouse & 1.71 & $\mathrm{~N}$ & .00 & .00 \\
\hline Eggplant & 3.38 & $N$ & .15 & .10 & Dog & 1.33 & $\mathrm{~N}$ & .00 & .00 \\
\hline Squash & 3.25 & $\mathrm{~N}$ & .20 & .20 & & \multicolumn{4}{|c|}{ Kitchen Utensil Category } \\
\hline Sweet Potato & 3.25 & $\mathrm{~N}$ & .00 & .00 & Fork & 9.42 & $\mathrm{Y}$ & .02 & .03 \\
\hline Beet & 3.17 & $N$ & .12 & & Spatula & 9.38 & $\mathrm{Y}$ & .02 & .03 \\
\hline Sunflower Seed & $\begin{array}{l}3.00 \\
2.92\end{array}$ & & $\begin{array}{l}.23 \\
.20\end{array}$ & $\begin{array}{l}.27 \\
.27\end{array}$ & Pan & 9.25 & $\mathrm{Y}$ & .03 & .07 \\
\hline $\begin{array}{l}\text { Peanut } \\
\text { Carrot }\end{array}$ & $\begin{array}{l}2.92 \\
2.88\end{array}$ & $\begin{array}{l}\mathrm{N} \\
\mathrm{N}\end{array}$ & .05 & .03 & Can Opener & 8.58 & $\mathbf{Y}$ & .02 & .03 \\
\hline $\begin{array}{l}\text { Carrot } \\
\text { Onion }\end{array}$ & 2.88 & $\mathrm{~N}$ & .02 & .03 & Pot Holder & 8.54 & $\mathrm{Y}$ & .05 & .10 \\
\hline Corn & 2.75 & $\mathrm{~N}$ & .08 & .10 & Toaster & 8.25 & $\mathbf{Y}$ & .20 & .13 \\
\hline \multirow[t]{3}{*}{ Chicken } & 1.04 & $\mathrm{~N}$ & .00 & .00 & Blender & 8.21 & $\mathbf{Y}$ & .13 & .13 \\
\hline & \multirow{2}{*}{\multicolumn{4}{|c|}{ Furniture Category }} & Plate & 8.13 & $\mathrm{Y}$ & .25 & .23 \\
\hline & & & & & Stove & 8.04 & $\mathrm{~N}$ & .47 & .40 \\
\hline Chair & 9.95 & $Y$ & .00 & .00 & Refrigerator & 7.38 & $Y$ & .33 & .13 \\
\hline Table & 9.83 & $\mathrm{Y}$ & .00 & .00 & Hot Plate & 7.33 & $\mathrm{Y}$ & .13 & .13 \\
\hline Bed & 9.58 & $\mathrm{Y}$ & .02 & .03 & Pitcher & 7.21 & $\mathrm{Y}$ & .20 & .20 \\
\hline Shelf & 6.41 & $\mathrm{Y}$ & .24 & .40 & Salt Shaker & 7.13 & $\mathrm{Y}$ & .25 & .30 \\
\hline Rug & 6.25 & $\mathrm{~N}$ & .48 & .10 & Dishwasher & 6.92 & $\mathbf{N}$ & .47 & .33 \\
\hline Lampshade & 5.70 & $\mathrm{Y}$ & .37 & .20 & Garbage Disposal & 6.54 & $Y$ & .45 & .21 \\
\hline Sewing Machine & 5.32 & $\mathrm{~N}$ & .11 & .10 & Mop & 6.46 & $\mathbf{Y}$ & .30 & .33 \\
\hline Stove & 5.28 & $\mathrm{~N}$ & .20 & .20 & Broom & 6.42 & $\mathrm{Y}$ & .37 & .20 \\
\hline
\end{tabular}




\begin{tabular}{|c|c|c|c|c|c|c|c|c|c|}
\hline $\begin{array}{l}\text { Candidate } \\
\text { Exemplar }\end{array}$ & $\begin{array}{l}\text { Typi- } \\
\text { cality }\end{array}$ & $\mathrm{MR}^{*}$ & NR* & WI* & $\begin{array}{l}\text { Candidate } \\
\text { Exemplar }\end{array}$ & $\begin{array}{l}\text { Typi- } \\
\text { cality }\end{array}$ & MR* & NR* & WI* \\
\hline Dustpan & 6.25 & $\mathbf{Y}$ & .35 & .30 & Biology & 9.87 & $\mathbf{Y}$ & .00 & .00 \\
\hline Soap & 5.71 & $\mathbf{N}$ & .28 & .17 & Physics & 9.83 & $\mathbf{Y}$ & .00 & .00 \\
\hline Spices & 5.38 & $\mathbf{N}$ & .13 & .13 & Astronomy & 9.33 & $Y$ & .02 & .03 \\
\hline Waste Basket & 5.13 & $\mathbf{N}$ & .22 & .30 & Oceanography & 8.87 & $\mathbf{Y}$ & .02 & .03 \\
\hline Washing Machine & 3.13 & $\mathbf{N}$ & .15 & .27 & Medicine & 8.62 & $\mathbf{Y}$ & .06 & .10 \\
\hline Pencil & 2.96 & $\mathbf{N}$ & .10 & .13 & Anatomy & 8.50 & $\mathbf{Y}$ & .07 & .06 \\
\hline Hammer & 2.71 & $\mathbf{N}$ & .08 & .10 & Meteorology & 8.37 & $Y$ & .00 & .00 \\
\hline \multirow[t]{3}{*}{ Television } & 1.71 & $\mathbf{N}$ & .00 & .00 & Mineralogy & 8.12 & $\mathrm{Y}$ & .00 & .00 \\
\hline & \multirow{2}{*}{\multicolumn{4}{|c|}{ Natural Earth Formation Category }} & Psychology & 7.79 & $\mathbf{Y}$ & .06 & .10 \\
\hline & & & & & Engineering & 7.70 & $\mathrm{Y}$ & .09 & .03 \\
\hline $\begin{array}{l}\text { Mountain } \\
\text { Volcano }\end{array}$ & $\begin{array}{l}9.75 \\
9.13\end{array}$ & $\begin{array}{l}\mathrm{Y} \\
\mathrm{Y}\end{array}$ & .00 & .00 & Metallurgy & 7.62 & $\mathbf{Y}$ & .08 & .14 \\
\hline Volcano & 9.13 & $Y$ & .03 & .07 & Dentistry & 7.12 & $\mathrm{Y}$ & .20 & .13 \\
\hline Plateau & 9.04 & $\mathrm{Y}$ & .00 & .00 & Nursing & 6.70 & $\mathrm{Y}$ & .49 & .10 \\
\hline Fault & 8.87 & $Y$ & .09 & .03 & Pharmacy & 6.66 & $\mathbf{Y}$ & .32 & .27 \\
\hline Cliff & 8.50 & $\mathbf{Y}$ & .00 & .00 & Nutrition & 6.62 & $\mathrm{Y}$ & .16 & .24 \\
\hline Island & 8.50 & $Y$ & .00 & .00 & Archaeology & 6.50 & $\mathrm{Y}$ & .15 & .16 \\
\hline Desert & 8.43 & $\mathbf{Y}$ & .13 & .07 & Anthropology & 6.41 & $\mathbf{Y}$ & .22 & .03 \\
\hline Valley & 8.42 & $\mathbf{Y}$ & .02 & .03 & Geometry & 6.29 & $\mathrm{Y}$ & .45 & .34 \\
\hline Continent & 8.08 & $Y$ & .03 & .07 & Agriculture & 6.28 & $\mathrm{Y}$ & .09 & .10 \\
\hline Strait & 8.04 & $\mathbf{Y}$ & .07 & .07 & Criminology & 6.16 & $\mathrm{Y}$ & .19 & .10 \\
\hline Peninsula & 8.00 & $\mathrm{Y}$ & .02 & .03 & Economics & 6.04 & $\mathrm{Y}$ & .29 & .10 \\
\hline Glacier & 7.42 & $\mathrm{Y}$ & .15 & .17 & Geography & 5.66 & $\mathbf{Y}$ & .30 & .26 \\
\hline Waterfall & 7.42 & $\mathrm{Y}$ & .05 & .10 & Architecture & 5.16 & $Y$ & .50 & .24 \\
\hline Beach & 7.38 & $\mathrm{Y}$ & .00 & .00 & Sociology & 5.00 & $\mathrm{Y}$ & .35 & .30 \\
\hline Stalagmite & 7.36 & Y & .02 & .04 & Linguistics & 4.83 & $\mathrm{Y}$ & .22 & .16 \\
\hline River & 7.33 & $\mathrm{Y}$ & .07 & .07 & Politics & 4.00 & $\mathrm{~N}$ & .48 & .13 \\
\hline Reef & 7.25 & $Y$ & .12 & .10 & Philosophy & 3.79 & $\mathbf{N}$ & .44 & .06 \\
\hline Geyser & 7.17 & $\mathrm{Y}$ & .03 & .07 & History & 3.54 & $\mathrm{~N}$ & .32 & .17 \\
\hline Boulder & 7.08 & $\mathrm{Y}$ & .12 & .17 & Advertising & 3.12 & $\mathrm{~N}$ & .30 & .20 \\
\hline Ocean & 7.08 & $\mathrm{Y}$ & .08 & .10 & & \multirow{2}{*}{\multicolumn{4}{|c|}{ Ship Category }} \\
\hline Stone & 7.04 & $\mathrm{Y}$ & .17 & .27 & & & & & \\
\hline Iceberg & 6.58 & $\dot{\mathrm{Y}}$ & .33 & .24 & Ocean Liner & 9.92 & Y & .00 & .00 \\
\hline Forest & 6.54 & $\mathrm{Y}$ & .50 & .27 & Tanker & 9.13 & $\mathrm{Y}$ & .00 & .00 \\
\hline Meadow & 6.54 & $\mathrm{Y}$ & .27 & .27 & Aircraft Carrier & 9.08 & $\mathbf{Y}$ & .05 & .03 \\
\hline Sinkhole & 6.06 & $\mathbf{Y}$ & .07 & .00 & Coast Guard Cutter & 8.58 & $\mathrm{Y}$ & .12 & .18 \\
\hline Tropics & 4.79 & $\mathrm{~N}$ & .47 & .40 & Trawler & 7.71 & $\mathrm{Y}$ & .07 & .14 \\
\hline Cloud & 4.42 & $\mathbf{N}$ & .18 & .10 & Tugboat & 7.58 & $\mathrm{Y}$ & .27 & .13 \\
\hline Air & 3.13 & $\mathrm{~N}$ & .28 & .30 & Sailboat & 7.54 & $\mathrm{Y}$ & .35 & .10 \\
\hline \multirow[t]{2}{*}{ House } & 1.17 & $N$ & .00 & .00 & Submarine & 7.38 & $\mathrm{Y}$ & .15 & .17 \\
\hline & \multirow{2}{*}{\multicolumn{4}{|c|}{ Precious Stone Category }} & Riverboat & 6.96 & $\mathbf{Y}$ & .13 & .13 \\
\hline Diamond & 996 & $\mathrm{Y}$ & & & Barge & 6.46 & $Y$ & .20 & .27 \\
\hline Emerald & $\begin{array}{l}9.90 \\
971\end{array}$ & $\mathbf{Y}$ & .00 & .00 & Lifeboat & 6.46 & $\mathrm{Y}$ & .42 & .03 \\
\hline $\begin{array}{l}\text { Emerald } \\
\text { Sapphire }\end{array}$ & & $\mathrm{Y}$ & .00 & .00 & Catamaran & 6.43 & $\mathrm{Y}$ & .33 & .08 \\
\hline $\begin{array}{l}\text { Sapphire } \\
\text { Opal }\end{array}$ & 9.29 & $\mathrm{Y}$ & .03 & .07 & Rowboat & 6.42 & $\mathrm{Y}$ & .43 & .07 \\
\hline $\begin{array}{l}\text { Opal } \\
\text { Jade }\end{array}$ & 8.42 & $\mathrm{Y}$ & .03 & .00 & Houseboat & 6.29 & $\mathrm{Y}$ & .33 & .20 \\
\hline & 7.79 & $Y$ & .07 & .07 & Kayak & 5.79 & Y & .46 & .07 \\
\hline $\begin{array}{l}\text { Topaz } \\
\text { Turquoise }\end{array}$ & 7.71 & $\mathrm{Y}$ & .07 & .07 & Canoe & 5.67 & $\mathbf{Y}$ & .42 & .10 \\
\hline Turquoise & 7.58 & $Y$ & .12 & .17 & Racing Shell & 5.30 & $Y$ & .50 & .13 \\
\hline Pearl & 7.42 & $\mathrm{Y}$ & .30 & .27 & Spacecraft & 5.29 & $\mathbf{Y}$ & .37 & .27 \\
\hline Garnet & 7.17 & $\mathrm{Y}$ & .21 & .19 & Sampan & 5.27 & $\mathbf{Y}$ & .25 & .13 \\
\hline Onyx & 7.13 & $\mathrm{Y}$ & .25 & .25 & Raft & 5.00 & $\mathbf{Y}$ & .45 & .10 \\
\hline Aquamarine & 6.19 & $\mathrm{Y}$ & .26 & .12 & Hovercraft & 4.80 & $\mathrm{Y}$ & .37 & .13 \\
\hline Cultured Pearl & 6.13 & $\mathrm{Y}$ & .47 & .41 & Gondola & 4.63 & $\mathrm{Y}$ & .47 & .17 \\
\hline Zircon & 5.80 & $\mathrm{Y}$ & .42 & .17 & Toy Boat & 4.58 & $\mathrm{~N}$ & .42 & .03 \\
\hline Industrial Diamond & 5.74 & $\mathbf{N}$ & .30 & .27 & Surfboard & 2.96 & $\mathbf{N}$ & .17 & .20 \\
\hline Gold & 5.54 & $\mathrm{~N}$ & .43 & .27 & Buoy & 2.75 & $\mathrm{~N}$ & .03 & .07 \\
\hline Agate & 5.52 & Y & .35 & .26 & Life Jacket & 2.67 & $\mathrm{~N}$ & .12 & .17 \\
\hline Moon Rock & 5.19 & $\mathrm{~N}$ & .44 & .15 & Torpedo & 2.30 & $\mathrm{~N}$ & .12 & .17 \\
\hline Rhinestone & 4.83 & $\mathrm{~N}$ & .38 & .17 & Driftwood & 2.25 & $\mathbf{N}$ & .07 & .07 \\
\hline Uranium & 4.79 & $\mathbf{N}$ & .24 & .21 & & \multirow{2}{*}{\multicolumn{4}{|c|}{ Sport Category }} \\
\hline Quartz & 4.63 & $\mathbf{N}$ & .43 & .20 & & & & & \\
\hline Mica & 3.96 & $\mathbf{N}$ & .17 & .14 & Football & 9.71 & $\mathrm{Y}$ & .00 & .00 \\
\hline Granite & 3.25 & $\mathbf{N}$ & .10 & .07 & Swimming & 9.58 & $\mathbf{Y}$ & .00 & .00 \\
\hline Glass & 2.04 & $\mathbf{N}$ & .00 & .00 & Skiing & 9.08 & $\mathbf{Y}$ & .02 & .03 \\
\hline Wood & 1.58 & $\mathrm{~N}$ & .00 & .00 & Gymnastics & 8.88 & $\mathrm{Y}$ & .00 & .00 \\
\hline Paper & 1.13 & $\mathrm{~N}$ & .00 & .00 & Ice Skating & 8.33 & $Y$ & .05 & .10 \\
\hline \multirow[t]{3}{*}{ Cotton } & 1.07 & $\mathrm{~N}$ & .00 & .00 & Pole Vaulting & 8.04 & $\mathbf{Y}$ & .00 & .00 \\
\hline & \multirow{2}{*}{\multicolumn{4}{|c|}{ Science Category }} & Woightlifting & 7.75 & $\mathrm{Y}$ & .02 & .03 \\
\hline & & & & & llorseback Riding & 7.67 & $\mathrm{Y}$ & .02 & .03 \\
\hline Chemistry & 9.95 & $\mathrm{Y}$ & .00 & .010 & Surfinṇ় & 7.46 & $\mathrm{Y}$ & .03 & .07 \\
\hline
\end{tabular}




\begin{tabular}{|c|c|c|c|c|}
\hline $\begin{array}{l}\text { Candidate } \\
\text { Exemplar }\end{array}$ & $\begin{array}{l}\text { Typi- } \\
\text { cality }\end{array}$ & $\mathrm{MR}^{*}$ & $\mathrm{NR}^{*}$ & WI* \\
\hline Golf & 7.42 & $\mathrm{Y}$ & .02 & .03 \\
\hline Bowling & 7.29 & $Y$ & .10 & .13 \\
\hline Archery & 7.21 & $Y$ & .03 & .07 \\
\hline Jogging & 6.88 & $\mathrm{Y}$ & .15 & .17 \\
\hline Fishing & 6.67 & $\mathrm{Y}$ & .17 & .13 \\
\hline Bullfighting & 6.17 & $\mathrm{Y}$ & .20 & .07 \\
\hline Hunting & 6.13 & $\mathrm{Y}$ & .17 & .13 \\
\hline Fox Hunting & 5.96 & $\mathrm{Y}$ & .17 & .20 \\
\hline Croquet & 5.67 & $\mathrm{Y}$ & .17 & .20 \\
\hline Billiards & 5.54 & $\mathrm{Y}$ & .23 & .20 \\
\hline Horseshoes & 5.29 & $\mathrm{Y}$ & .22 & .23 \\
\hline Shuffleboard & 5.29 & $\mathrm{Y}$ & .23 & .20 \\
\hline Dueling & 5.00 & $\mathrm{Y}$ & .22 & .23 \\
\hline Darts & 4.79 & $\mathrm{Y}$ & .29 & .24 \\
\hline Chess & 4.21 & $\mathrm{Y}$ & .48 & .23 \\
\hline Roulette & 3.74 & $\mathrm{~N}$ & .33 & .07 \\
\hline Writing & 1.54 & $\mathrm{~N}$ & .10 & .07 \\
\hline \multirow[t]{2}{*}{ Watching Television } & 1.46 & $\mathrm{~N}$ & .03 & .00 \\
\hline & \multicolumn{4}{|c|}{ Vegetable Category } \\
\hline Carrot & 9.29 & $\mathrm{Y}$ & .03 & .07 \\
\hline Celery & 9.13 & $Y$ & .05 & .10 \\
\hline Lettuce & 9.00 & $\mathrm{Y}$ & .02 & .03 \\
\hline Corn & 8.83 & $\mathrm{Y}$ & .08 & .10 \\
\hline Radish & 8.46 & $\mathrm{Y}$ & .00 & .00 \\
\hline Onion & 8.38 & $Y$ & .02 & .03 \\
\hline Turnip & 8.33 & $\mathrm{Y}$ & .00 & .00 \\
\hline Eggplant & 8.29 & $\mathrm{Y}$ & .12 & .10 \\
\hline Artichoke & 8.21 & $\mathrm{Y}$ & .00 & .00 \\
\hline Watercress & 7.76 & $\mathrm{Y}$ & .07 & .07 \\
\hline Parsley & 7.63 & $\mathrm{Y}$ & .10 & .14 \\
\hline Potato & 7.54 & $\mathrm{Y}$ & .10 & .20 \\
\hline Yam & 7.22 & $\mathrm{Y}$ & .05 & .03 \\
\hline Tomato & 6.96 & $\mathrm{Y}$ & .32 & .23 \\
\hline Rhubarb & 6.83 & $\mathrm{Y}$ & .09 & .03 \\
\hline Mushroom & 6.38 & $Y$ & .20 & .20 \\
\hline Soybean & 6.33 & $\mathrm{Y}$ & .03 & .07 \\
\hline Pickle & 5.92 & $\mathrm{Y}$ & .17 & .20 \\
\hline Pumpkin & 5.71 & $\mathrm{Y}$ & .35 & .17 \\
\hline Rice & 5.46 & $\mathrm{Y}$ & .33 & .27 \\
\hline Sauerkraut & 5.13 & $Y$ & .22 & .23 \\
\hline Olive & 4.92 & $\mathrm{Y}$ & .45 & .23 \\
\hline Peanut & 4.46 & $\mathrm{Y}$ & .48 & .30 \\
\hline Sugar Cane & 4.09 & $Y$ & .50 & .40 \\
\hline Apple & 3.13 & $\mathrm{~N}$ & .05 & .10 \\
\hline Dandelion & 3.00 & $\mathrm{~N}$ & .24 & .21 \\
\hline Raisin & 2.67 & $\mathrm{~N}$ & .08 & .10 \\
\hline Noodles & 2.42 & $\mathrm{~N}$ & .10 & .07 \\
\hline Bread & 2.08 & $\mathrm{~N}$ & .00 & .00 \\
\hline \multirow[t]{2}{*}{ Steak } & 1.17 & $\mathrm{~N}$ & .00 & .00 \\
\hline & \multicolumn{4}{|c|}{ Vehicle Category } \\
\hline Car & 10.00 & $Y$ & .00 & .00 \\
\hline Bus & 9.79 & $Y$ & .00 & .00 \\
\hline Airplane & 8.96 & $\mathrm{Y}$ & .03 & .07 \\
\hline Carriage & 7.83 & $Y$ & .02 & .03 \\
\hline Tractor & 7.67 & $\mathrm{Y}$ & .00 & .00 \\
\hline Horse Van & 7.27 & $\mathrm{Y}$ & .00 & .00 \\
\hline Wheelchair & 6.96 & $\mathrm{Y}$ & .18 & 17 \\
\hline Unicycle & 6.88 & $Y$ & .13 & .20 \\
\hline Blimp & 6.79 & $\mathrm{Y}$ & .12 & .10 \\
\hline Canoe & 6.79 & $\mathrm{Y}$ & .15 & 10 \\
\hline Raft & 6.67 & $Y$ & .17 & .13 \\
\hline Baby Carriage & 6.46 & $\mathrm{Y}$ & .22 & .17 \\
\hline Elevator & 6.13 & $\mathrm{Y}$ & .22 & .17 \\
\hline Roller Skate & 6.00 & $\mathrm{Y}$ & .40 & .20 \\
\hline Skatcboard & 6.00 & $Y$ & .32 & 17 \\
\hline
\end{tabular}

\begin{tabular}{|c|c|c|c|c|}
\hline $\begin{array}{l}\text { Candidate } \\
\text { Exemplar }\end{array}$ & $\begin{array}{l}\text { Typi- } \\
\text { cality }\end{array}$ & $\mathrm{MR}^{*}$ & NR* & $\mathrm{WI}^{*}$ \\
\hline Escalator & 5.96 & $\mathrm{Y}$ & .35 & .10 \\
\hline Sled & 5.79 & $\mathbf{Y}$ & .20 & .07 \\
\hline Pogo Stick & 5.08 & $\mathrm{Y}$ & .45 & .17 \\
\hline Surfboard & 5.04 & $\mathrm{~N}$ & .47 & .13 \\
\hline Feet & 4.83 & $\mathrm{~N}$ & .32 & .17 \\
\hline Conveyor Belt & 4.54 & $\mathrm{Y}$ & .42 & .17 \\
\hline Stretcher & 4.50 & $\mathrm{Y}$ & .38 & .30 \\
\hline Parachute & 4.38 & $\mathrm{~N}$ & .48 & .30 \\
\hline Ferris Wheel & 3.71 & $\mathrm{~N}$ & .32 & .10 \\
\hline Shoes & 2.67 & $\mathrm{~N}$ & .07 & .13 \\
\hline Cannon & 1.96 & $\mathrm{~N}$ & .02 & .03 \\
\hline Table & 1.25 & $\mathrm{~N}$ & .00 & .00 \\
\hline \multirow[t]{2}{*}{ Apartment } & 1.13 & $\mathrm{~N}$ & .00 & .00 \\
\hline & \multicolumn{4}{|c|}{ Weather Phenomenon Category } \\
\hline Rain & 9.71 & $\mathrm{Y}$ & .00 & .00 \\
\hline Thunder & 9.38 & $\mathrm{Y}$ & .00 & .00 \\
\hline Wind & 9.29 & Y & .02 & .03 \\
\hline Clear Sky & 8.96 & $\mathrm{Y}$ & .02 & .03 \\
\hline Hurricane & 8.96 & Y & .00 & .00 \\
\hline Cloud & 8.67 & $\mathbf{Y}$ & .05 & .10 \\
\hline Rainbow & 8.17 & $\mathrm{Y}$ & .00 & .00 \\
\hline Drought & 7.96 & $\mathrm{Y}$ & .02 & .03 \\
\hline Icicles & 6.96 & Y & .20 & .20 \\
\hline Dew & 6.58 & Y & .03 & .07 \\
\hline Tidal Wave & 6.17 & $Y$ & .33 & .27 \\
\hline Ice Age & 6.08 & $Y$ & .20 & .20 \\
\hline Autumn & 5.83 & $\mathrm{~N}$ & .45 & .30 \\
\hline Glacier & 5.58 & $\mathrm{~N}$ & .45 & .17 \\
\hline Iceberg & 4.92 & $\mathrm{~N}$ & .45 & .30 \\
\hline Jet Stream & 4.76 & $\mathrm{Y}$ & .46 & .21 \\
\hline Desert & 4.50 & $\mathrm{~N}$ & .18 & .17 \\
\hline Earthquake & 4.38 & $\mathrm{~N}$ & .28 & .17 \\
\hline Avalanche & 4.33 & $\mathrm{~N}$ & .27 & .27 \\
\hline Tides & 4.13 & $\mathrm{~N}$ & .47 & .27 \\
\hline Sunspots & 3.96 & $\mathrm{~N}$ & .34 & .14 \\
\hline Eclipse & 3.83 & $\mathrm{~N}$ & .18 & .23 \\
\hline Sunrise & 3.79 & $\mathrm{~N}$ & .23 & .20 \\
\hline Air Pollution & 3.67 & $\mathrm{~N}$ & .13 & .20 \\
\hline Twilight & 3.33 & $\mathrm{~N}$ & .17 & .07 \\
\hline Waterspout & 3.27 & $\mathrm{Y}$ & .48 & .13 \\
\hline Volcano Eruption & 3.17 & $\mathrm{~N}$ & .20 & .07 \\
\hline Fallout & 3.04 & $\mathrm{~N}$ & .14 & .00 \\
\hline Air Conditioning & 2.63 & $\mathrm{~N}$ & .02 & .03 \\
\hline
\end{tabular}

\section{REFERENCE NOTE}

1. McCloskey, M., \& Glucksberg. S. Decision processes in rintiving cluss inclusion statements: Implications for models of semuntic menory. Manuscript submitted for publication, $19 \%$

\section{REFERENCES}

ANDERSON. J. R.. \& Bower. G. Human associative memon'. Washington. D.C: V. H. Winston, 1973.

Battic, W. F.. \& Montague, W. E. Category norms for verbal items in 50 caltegories: A replication and extension af the Connceticat category norms. Joumal of Experimental Prichologe Monograph, 1909. 8013. Part 2).

Bolikne. L. E., Ekstrand. B. R.. \& Dominowski, R. L. The fracholegy of thinking. Englewood Cliffs. N.J: PrenticeHaill. 19\%. 
Clark, H. H. The language-as-fixed-effect fallacy: A critique of language statistics in psychological research. Journal of Verbal Learning and Verbal Behavior, 1973, 12, 335-359.

Collins, A. M., \& Quillian, M. R. Retrieval time from semantic memory. Joumal of Verbal Leaming and Verbal Behavior. 1969, 8, 240-247.

Collins, A. M., \& Quillian, M. R. Does category size affect categorization time? Journal of Verbal Learning and Verbal Behavior, 1970, 9, 432-438.

Collins, A. M., \& Quillian, M. R. Experiments on semantic menory and language comprehension. In L. W. Gregg (Ed.). Cognition in learning and memory. New York: Wiley. 1972.

Glass, A. L.. \& Holyoak, K. J. Alternative conceptions of semantic memory. Cognition, 1974/75, 3, 313-339.

Hersch, H. M., \& Caramazza, A. A fuzzy set approach to modifiers and vagueness in natural language. Journal of Experimental Psychology: General, 1976, 105, 254-276.

$\mathrm{KinTSCH}, \mathrm{W}$. The representation of meaning in memory. Hillsdale, N.J: Lawrence Erlbaum, 1974.

Miller, G. A.. \& Johnson-Laird, P. N. Language and perception. Cambridge, Mass: The Belknap Press of Harvard University Press. 1976.

MEYER. D. E. On the representation and retrieval of stored semantic information. Cognitive Psychology, 1970, 1, 242-299.

Oden. G. C. Fuzziness in semantic memory: Choosing exemplars of subjective categories. Memory \& Cognition, 1977, 5, 198-204.

Rips, L. J.. Shoben, E. J., \& Sмith, E. E. Semantic distance and the verification of semantic relations. Journal of Verbal Le'arming and Verbal Behavior, 1973, 12. 1-20.

Roscr. E. On the internal structure of perceptual and semantic categories. In T. E. Moore (Ed.), Cognitive development and the acquisition of language. New York: Academic Press, 1973.

Rosch. E.. \& Mervis, C. B. Family resemblances: Studies in the internal structure of categories. Cognitive Psychology, 1975. 7. 573-605.
SmIth. E. E. Theories of semantic memory. In W. K. Estes (Ed.), Handbook of learning and cognitive processes (Vol. 5). Hillsdale. N.j: Lawrence Eribaum, in press.

Sмiтн, E. E., Shoben, E. J., \& Rips, L. J. Structure and process in semantic menory: A featural model for semantic decisions. Psychological Review', 1974, 81, 214-241.

Wittgenstein, L. [Philosophical investigations] (G. E. M. Anscombe, trans.). Oxford: Blackwell, 1953.

ZaDEH, L. A. Fuzzy sets. Information and Control, 1965. 8. 338-353.

\section{NOTES}

1. The proportion of nonmodal responses was calculated using data from both Session 1 and Session 2. Therefore, in interpreting this proportion as a measure of between-subjects disagreement, we are in effect treating the two decisions made by a subject about each pair as if they were from two different subjects. This is a conservative procedure for measuring intersubject disagreement, because agreement should be (and is) higher within than between subjects.

2. Note that our assumptions maximize the probability that different functional categories will be chosen by a subject in the two sessions. If one functional category is more frequent or salient than the other(s) and so has a higher probability of being selected in each session, then the probability of different categories being used in the two sessions is lower than if all categories are equally likely to be chosen. The probability that different categories will be used would, of course, also be lower than estimated if for any other reason (e.g., memory for the previous session, similarly of general context) the subject had some tendency to select the same functional category in Session 2 as in Session 1.

(Received for publication October 3, 1977; revision accepted February 1, 1978.) 